\title{
A simple method for assessing preliminary conservation status of plants at a national level: a case study using the ferns of El Salvador
}

\author{
SANDRA KNAPP and Jorge MONTERROSA SALOMÓN
}

\begin{abstract}
Assessments of conservation status are usually carried out on a global scale but national priorities often necessitate a more focused approach. Using a typology of rarity first articulated in the early 1980s by Deborah Rabinowitz, coupled with presence/absence from protected areas, preliminary conservation status at the national level was assessed for 397 species of ferns and fern allies from El Salvador in Central America. Of these, 43 lacked sufficient data, 175 were considered not of conservation concern, 106 were considered to be at risk and 73 to be threatened. The majority of the threatened species were from cloud or montane forest habitats but aquatics and species restricted to pine-oak forests are also rare and occur outside protected areas. The utility of this simple methodology is discussed and the importance of field studies by local experts with local knowledge emphasized.
\end{abstract}

Keywords Central America, El Salvador, ferns, forests, Global Strategy for Plant Conservation, lycophytes, rarity

\section{Introduction}

That we are entering a biodiversity crisis of unparalleled 1 magnitude and speed is now widely acknowledged (MEA, 2005). Scientific and public understanding of the scale of biodiversity loss is less clearly understood, despite the baseline implicit in the 2010 targets set by the global community through the Convention on Biological Diversity to '. . achieve, by 2010, a significant reduction of the current rate of biodiversity loss at the global, regional and national levels as a contribution to poverty alleviation and to the benefit of all life on earth' (COP Decision VI/26). Lessons learned from these targets, however, will inform new policies set up in their wake (Fisher, 2009; Walpole et al., 2009). In addition to knowledge of the baseline levels of biodiversity, such as species' numbers, distributions and abundances, knowledge of the threat status of individual species is important for implementing conservation actions at the species' level and establishing baselines for extinction risk.

SANDRA KNAPP (Corresponding author) Department of Botany, Natural History Museum, Cromwell Road, London, SW7 5BD, UK. E-mail s.knapp@ nhm.ac.uk

Jorge Monterrosa SAlomón Asociación Jardín Botánico La Laguna, Urbanización Industrial Plan de La Laguna, Antiguo Cuscatlán, El Salvador

Received 23 July 2009. Revision requested 5 October 2009.

Accepted 6 November 2009.
Progress on the development of indicators for biodiversity has been patchy (Walpole et al., 2009) but those associated with changes in status of threatened species are well known. The IUCN Red List system for categorizing extinction risk to species (IUCN, 2001) is widely used and is the most comprehensive quantitative method for determining threat on a global scale (Rodrigues et al., 2006).

The Red List ranks taxa according to their extinction risk, and assessments for the Red List compile current knowledge of conservation status and threats to individual species. Few plants, however, have been formally assessed using the IUCN system; only c. $3 \%$ of plant species (of an estimated c. 400,000) have been fully assessed (IUCN, 2009). This has been attributed to lack of specialists, multiple systems for classifying plants at risk and the formulation of the categories and criteria themselves (Brummitt et al., 2008). Target 2 of the Global Strategy for Plant Conservation is 'a preliminary assessment of the conservation status of all known plant species, at national, regional and international levels' (UNEP, 2002). An increase in the speed of plant conservation assessment is necessary if this target is to be met. Various approaches to provide the information necessary for 'first-cut' assessments have been proposed, including using information from herbarium labels (Callmander et al., 2005; Krupnick et al., 2008) as a reliable surrogate. The software Rapid List (RAMAS, 2007) has been developed to establish preliminary assessments: it guides a user through a series of questions designed to indicate whether or not a species is likely to fall into any of the threatened categories, which are presumed then to be refined using the more stringent IUCN criteria. Brummitt et al. (2008) proposed using a 'desktop' approach using geographical information system (GIS) software and georeferenced herbarium specimens but incorporating other data from labels to add much-needed information about existing threats, population sizes or local abundance. Few plant taxa have been assessed by any of these methods.

An additional complication in addressing Target 2 of the Global Strategy for Plant Conservation is its emphasis on assessments at three levels, national, regional and international (global). The IUCN Red Lists and many of the firstcut techniques proposed and currently in use focus on global assessments, as it is those taxa threatened with extinction on a global level about which we probably ought to have the most concern. Biodiversity and conservation policies, however, are implemented at a national level, and 
what is important or rare nationally may not be globally or even regionally threatened. In addition, local expertise is held nationally, and it is that local knowledge of plant abundances and distributions that will prove essential to a national, and ultimately to a global, implementation of plant conservation.

Many years before the current emphasis on extinction risk and plant distribution, Rabinowitz (1981) suggested that species become rare (and by extension subject to extinction risk) by a variety of pathways and if this were so, the ecological and evolutionary consequences of rarity would be diverse. She analysed plant rarity using a scheme that took into account range size, habitat specificity and local abundance (population size). The various combinations of these variables resulted in eight potential categories of rarity (see Fig. 1 of Rabinowitz, 1981), only seven of which were apparently occupied (the eighth, species that had small geographic range, wide habitat specificity and small population size, was postulated as non-existent; see Fig. 2 of Rabinowitz, 1981). Her typology for rare species ranged from 'common' to 'endemics', and the scheme was used to discuss the ecological consequences of rarity in terms of competition and coexistence and the selective pressures likely to face rare taxa of the different sorts. This scheme, with the three variables of distribution, habitat and abundance, can be used as a simple method to assess the rarity of plants at any scale and to establish a preliminary conservation status for a large numbers of species at a scale appropriate for subsequent conservation action.

Ferns and fern allies (Pryer et al., 2001, 2004; Smith et al., 2008) have been characterized as the amphibians of the plant world (Page, 1985). They are sensitive indicators of environmental change (Tuomisto \& Poulsen, 1996; Tuomisto, 2006), due at least in part to their relative habitat specificity (Young \& León, 1989; Given, 1993) and have been used as monitors of habitat pollution in temperate zones (Klekowski, 1982). In contrast to their perceived narrow habitat specificity, the majority of ferns and fern allies tend to have relatively wide distributional ranges compared to flowering plants (Wolf et al., 2001; Moran, 2008), even in tropical areas such as Mesoamerica (Davidse et al., 1995). They therefore represent a group where national conservation assessments may be at odds with assessments at a global level. This is particularly true for a small country, such as El Salvador, which has a land area of $21,000 \mathrm{~km}^{2}$ and only c. $7 \%$ of the land surface forested (Ventura \& Villacorta, 2001). This represents a significant reduction from the estimated 99.5\% forest cover estimated to have been in place prior to human occupation (Holdridge, 1975) and suggests that a huge proportion of El Salvador's fern diversity is at risk, if not already seriously compromised. Only c. $0.5 \%$ of El Salvador's fern diversity is endemic, despite the relatively high species' diversity per land area (Monterrosa Salomón \& Monro, 2008).
Following the comprehensive regional overview provided by the volume on ferns of Flora Mesoamericana (Davidse et al., 1995), recent studies (Monterrosa Salomón \& Monro, 2008; Monterrosa Salomón et al., 2009) have documented 397 species of ferns and fern allies in El Salvador, many of these revealed during recent fieldwork. Of these, only the tree ferns (13 species in the families Cibotiaceae, Culcitaceae, Cyatheaceae and Dicksoniaceae) have had any sort of conservation assessment; these are listed as either at risk or threatened by MARN (2004) and many are also listed on Appendix II of CITES (as are all American species of Cyatheaceae). The national biodiversity strategy of El Salvador (MARN, 2000) has at its heart inventory and monitoring, and a Darwin Initiative project initiated in 2006 used ferns and fern allies as indicators for use in the monitoring of ecosystem health in the country. Countries in the temperate zones with relatively low diversity are well-positioned to complete national assessments for all plant groups (Cheffings et al., 2005) in a timely fashion. Tropical countries, such as El Salvador, with higher levels of biodiversity, are more complex and potentially problematic for national assessments, and the international scientific community remains focused on providing global level assessments of conservation status. In addition, developing countries, with great interest in assessing national biodiversity and threat, often do not have access to some of the technologies used in most global first-cut assessments.

In this study we use field data collected on the ferns and fern allies of El Salvador, with Rabinowitz's (1981) categories of rarity, to develop a simple methodology for providing a preliminary conservation assessment at the national level for these indicator groups. We aimed to facilitate future focus of monitoring efforts, inventory and conservation prioritization.

\section{Methods}

Using a previously published checklist of fern and fern allies (Monterrosa Salomón \& Monro, 2008) based on an initial floristic account (Davidse et al., 2005), coupled with distribution data and abundance observations compiled as part of a Darwin Initiative project (Monterrosa Salomón et al., 2009), we gave each species in El Salvador a score based on Rabinowitz's (1981) categories of rarity (Table 1). Species for which we did not have adequate knowledge on any one of the parameters were scored as lacking sufficient data for analysis. These scores were summed, giving each species a score between 0 and 3 , with a score of o indicating rarity and 3 indicating commonness (raw scores for all species can be obtained from the authors and will be placed online at the website of the Jardín Botánico La Laguna, 2010).

We then used a simple binary yes or no (presence/ absence) to determine if a species was known from within any one of the protected areas of El Salvador, which 
TABLE 1 Scheme for scoring rarity attributes for the ferns and fern allies of El Salvador (modified from Rabinowitz, 1981).

\begin{tabular}{lll}
\hline Parameter & State & Score \\
\hline Range & $\begin{array}{l}\text { Narrowly distributed in } \\
\text { El Salvador } \\
\text { (1-2 departments) }\end{array}$ & 0 \\
& $\begin{array}{l}\text { Widely distributed in } \\
\text { El Salvador } \\
\text { ( } \geq 3 \text { departments) }\end{array}$ & 1 \\
Habitat specificity & $\begin{array}{l}\text { Restricted to a single } \\
\text { habitat type }\end{array}$ & 0 \\
& $\begin{array}{l}\text { Found in more than one } \\
\text { habitat type } \\
\text { Not abundant where it occurs } \\
\text { Local abundance }\end{array}$ & 0 \\
& Locally abundant & 1 \\
\hline
\end{tabular}

currently cover c. 3.5\% of the national territory (MARN, 2006). A combination of the rarity score and presence/ absence in protected areas was used to derive the preliminary conservation assessment at the national level (Table 2). Species occurring outside protected areas with scores of $\mathrm{o}$ or 1 were given a threatened status, those outside protected areas with a score of 2 were judged at risk as were those within protected areas with scores of 0 and 1 , and those with a score of 3 occurring either in or out of protected areas were judged not of particular conservation concern. Species for which there were insufficient data on distribution or abundance were scored for presence/absence in protected areas if the data were available but were not further assessed. All voucher specimens for distribution are cited in Monterrosa Salomón \& Monro (2008) or are deposited in LAGU (herbarium of the Jardín Botánico La Laguna).

\section{Results}

We recorded 397 species of fern and fern allies as present in El Salvador. Only 43 species (11\%) of these lacked sufficient data for analysis; these are taxa that are known only from single herbarium sheets or that have not been recollected recently (and thus local abundance is not known). Slightly under half of species $(175,44 \%)$ are not currently of conservation concern (the equivalent of the IUCN category Least Concern). Of those species considered of conservation concern, there are $106(27 \%)$ that were judged to be at risk and $73(18 \%)$ that are considered threatened (Table 2). The only endemic fern species in El Salvador are Anemia salvadorensis Mickel (assessed here as at risk) and Elaphoglossum microproductum A. Rojas (assessed here as threatened).

Tree ferns are subject to considerable interest, due largely to their use in trade. Of the 13 species of tree ferns in El Salvador assessed previously as at risk or threatened under current legislation (and on Appendix II of CITES because of their use in trade), only one is assessed as threatened using our method, a further eight as at risk, three as not of conservation concern and one as lacking sufficient data for assessment (Table 3). Of the taxa at some sort of risk, $89 \%$ occur in montane or cloud forest and $14 \%$ in oak-pine forest; an additional seven species (4\%) are aquatics or associated with lakes or swamps (percentages greater than $100 \%$ because of some habitat overlap). The habitat type with the largest number of species at risk is the cloud forest (threatened species, 36 of 73, and at-risk species, 62 of 106), an area of relatively small extent in El Salvador. All raw data for assessments are available from the authors on request and assessments are available on the website of the Jardín Botánico La Laguna (2010).

\section{Discussion}

Of the total described diversity of ferns and fern allies (c. 13,500), only $1.6 \%$ have been formally assessed using IUCN criteria (Arcand \& Ranker, 2008; IUCN, 2009). This is half the assessment effort for plants (defined by IUCN, 2009, as including red, brown and green algae, mosses and liverworts, ferns and fern allies, and flowering plants). Because ferns are sensitive indicators of habitat, habitat specific and usually associated with forests (Arcand \& Ranker,

TABle 2 Preliminary conservation assessment for the ferns and fern allies of El Salvador (see text for details of method). Spanish equivalents are: sin datos suficientes (data insufficient for analysis), no amenazada (not of conservation concern), en peligro (at risk) and amenazada (threatened).

\begin{tabular}{lllr}
\hline Compiled rarity index & $\begin{array}{l}\text { Presence in } \\
\text { protected area }\end{array}$ & Conservation status & $\begin{array}{c}\text { No. of fern species } \\
\text { in El Salvador }\end{array}$ \\
\hline 0 & Yes & At risk & 56 \\
0 & No & Threatened & 58 \\
1 & Yes & At risk & 46 \\
1 & No & Threatened & 15 \\
2 & Yes & Not of conservation concern & 60 \\
2 & No & At risk & 4 \\
3 & Yes & Not of conservation concern & 115 \\
3 & No & Not of conservation concern & 0 \\
& Yes/no & Data insufficient for analysis & 43 \\
\hline
\end{tabular}


TABLE 3 Conservation status of the tree ferns (Cibotiaceae, Culcitaceae, Cyatheaceae and Dicksoniaceae) of El Salvador.

\begin{tabular}{lll}
\hline & & Preliminary conservation \\
Species & Current conservation status & At risk \\
\hline Alsophila salvinii Hook. & Threatened (MARN, 2004) & At risk \\
Alsophila tryoniana (Gastony) D.S. Conant. & Threatened (MARN, 2004) & Not of conservation concern \\
Cibotium regale Verschaff. \& Lem. & At risk (MARN, 2004) & At risk \\
Culcita coniifolia (Hook.) Maxon & At risk (MARN, 2004) & Threatened \\
Cyathea bicrenata Liebm. & At risk (MARN, 2004); Appendix II CITES & Not of conservation concern \\
Cyathea costaricensis (Mett.) Domin & At risk (MARN, 2004); Appendix II CITES & At risk \\
Cyathea divergens Kunze var. tuerckheimii & At risk (MARN, 2004); Appendix II CITES & Data insufficient for analysis \\
$\quad$ (Maxon) R.M. Tryon & & At risk \\
Cyathea fulva (M. Martens \& Galeotti) Fée & Appendix II CITES & Not of conservation concern \\
Cyathea godmanii (Hook.) Domin & Threatened (MARN, 2004); Appendix II CITES & At risk \\
Cyathea scheideana (C. Presl) Domin & Threatened (MARN, 2004); Appendix II CITES & At risk \\
Dicksonia sellowiana Hook. & At risk (MARN, 2004); Appendix II CITES & At risk \\
Lophosoria quadripinnata (J.F. Gmel.) & Threatened (MARN, 2004) & \\
$\quad$ C. Chr. & At risk (MARN, 2004) & \\
Sphaeropteris horrida (Liebm.) & & \\
R.M. Tryon & &
\end{tabular}

2008), their assessment should be a priority. In addition, the relatively few species $(13,500$ vs c. 300,000 for flowering plants) means assessment of an entire monophyletic clade is feasible, even at a global scale. National level assessments, however, are important for policy implementation and the focusing of monitoring and research efforts. Our results more than double the number of fern species assessed at a preliminary level, at least at a national scale. Nationally, the two endemic species are a priority for conservation efforts, and both are of conservation concern. National level assessments for endemics, such as carried out using a similar method for Cuba (González-Torres et al., 2007), are the same as global assessments.

Most fern taxa have a wide distribution in Central America and the Neotropics (Davidse et al., 2005; Monterrosa Salomón \& Monro, 2008). Conservation assessments for such taxa are likely to differ significantly at national, regional and global levels; the degree to which these assessments at different scales vary may help in setting priorities nationally but, ultimately, national governments will decide how best to protect national biodiversity, based on the criteria they deem most relevant. This is often, but not always, on a national scale. Those taxa threatened nationally, for example, may be at range edges and thus of biological importance regionally although not of conservation concern if assessed on a regional scale. The relatively high proportion of species assessed as not particularly at risk means national conservation efforts can be focused on those species most at risk in El Salvador, particularly those 73 taxa considered threatened. These are perhaps underestimates as we have assumed that presence in a protected area affords at least some protection to plants; we did not assess the relative efficacy of protection in different protected areas.
The majority of threatened species occur in cloud or montane forest (common for ferns; Page, 1985) despite the presence of several such areas being under protection in El Salvador; several species restricted to pine-oak forests also fall into this category. Aquatics are also among those taxa assessed here as threatened, largely because of their occurrence outside any of El Salvador's protected areas and their extreme habitat limitations. Salvinia auriculata Aubl. is a good example of why this simple method is useful on a national scale. Although widely distributed throughout tropical America, S. auriculata is found in only a few lakes in El Salvador; it is thus of restricted distribution and restricted habitat and where it is found has a low population. On a global or regional scale, this species may not be of particular concern but in El Salvador ornaments fashioned from the leaves of $S$. auriculata are becoming common in shops. Each ornament is made from several individual plants and so a large industry could potentially affect populations severely. These ornaments are imported from nearby Guatemala but should the industry become established in El Salvador, the populations of S. auriculata could become seriously threatened.

The differences in our national level assessments of tree ferns as compared to the current listings (Table 3) mean that strategies for their local conservation can be tailored to national needs. Rather than relying on a broad-brush listing status, determined globally, for determining action, these fern species can be monitored nationally, with those most at risk receiving the highest level of protection, monitoring or further study. Cibotium regale, for example, is at risk according to MARN (Table 3) and not of particular conservation concern using our assessment method. In Asia, however, members of the genus Cibotium are at risk because of over-collection, thus illustrating the necessity for 
further, more in-depth assessment of particular threats and pressures. Two other tree ferns, Dicksonia sellowiana and Lophosoria quadripinnata, are both categorized as at risk but for different reasons. Lophosoria is common where it occurs but of restricted geographical range in the country, whereas Dicksonia is of a wider geographical range but not locally abundant. Individual species with the same status may require different conservation strategies.

We emphasize that our method is no substitute for a quantitative conservation assessment, particularly for threatened species. Our method is a way of quickly and easily setting priorities for further study or monitoring, prioritizing the georeferencing of herbarium specimens for use in GIS analyses (Brummitt et al., 2008) or for targeting species for in-depth study and observation. It is also useful in developing countries where access to GIS technology and software may not be in widespread use or where priorities are in the collection of field data rather than retrospective and time-consuming georeferencing (enabling the application of Criterion B of IUCN, 2009) of all national collections. In addition, many collections of plants from developing countries are held in herbaria in the developed world and access to these data is often (but increasingly less so with digitization programmes) not readily available to in-country scientists.

Rabinowitz's (1981) observation that different forms of rarity have different ecological consequences also applies to conservation. Different forms of rarity may necessitate different conservation actions, especially on a national scale in relation to protected areas. All species that have a score of o will need further study, some will be extremely rare and threatened nationally but others may just be under-recorded. Species with a score of 1 can be of three types: those with wide habitat preferences or that are distributionally common are potentially of less concern than those with high local abundance but narrow habitat specificity and distribution. The latter may also be because of under-reporting. Our use of occurrence in the administrative departments of $\mathrm{El}$ Salvador to score species for distributional range could be adapted to any scale but would need to be adapted, depending on the land area of interest (Rabinowitz, 1981; GonzálezTorres et al., 2007).

Recent criticisms of simplistic assessment and criteria for conservation (Orme et al., 2005; Wilson et al., 2009) have focused on incorporating complex factors, including an assessment of the costs of conservation actions, into priority setting. Although these criticisms are relevant at both a global and a national scale few taxa have sufficient data for application of some of these in-depth methods, particularly plants (Brummitt et al., 2008). Our method, while simplistic, is applicable at any scale but depends on good floristic knowledge, local expertise in taxonomy and identification (Monro et al., 2006), and local field knowledge. Without these three elements any sort of conservation assessment will be speculative. Regional compilations of plant diversity knowledge, floras, appear to have fallen from fashion, but are now more important than ever in implementing schemes for the conservation of plant diversity (Knapp, 2008; Knapp \& Press, 2010). Preliminary conservation assessments for plant species derived from a combination of data about distribution, habitat, abundance and presence (or absence) in a nation's protected areas provides a simple way to help implement Target 2 of the Global Strategy for Plant Conservation nationally and contributes to the priority setting implied in national biodiversity action plans. The combination of local knowledge of the components of biodiversity and their distribution has the potential to help develop and reinforce national capacities for conservation action and encourages national perspectives to coexist alongside global ones, for the benefit of both.

\section{Acknowledgements}

We thank the Darwin Initiative (Defra, UK Government) for funding work on ferns in El Salvador (project 640/15/ 015) and a Darwin Scholar Award to JMS in 2007 (EIDPS007), the Ministerio del Ambiente y Recursos Naturales (MARN) for collaboration in fieldwork and facilitation of fern collections in El Salvador, Harald Schneider for sharing his knowledge of ferns and their biology, and the dedicated staff of the protected areas of El Salvador for their participation and sharing their botanical knowledge.

\section{References}

ARCAND, N.N. \& RANKeR, T.A. (2008) Conservation biology. In Biology and Evolution of Ferns and Lycophytes (eds T.A. Ranker \& C.H. Hauffler), pp. 257-283. Cambridge University Press, Cambridge, UK.

Brummitt, N., Bachmann, S.P. \& Moat, J. (2008) Applications of the IUCN Red List: towards a global barometer for plant diversity. Endangered Species Research, 6, 127-135.

Callmander, M.W., Schatz, G.E. \& Lowry, II, P.P. (2005) IUCN Red List assessment and the Global Strategy for Plant Conservation: taxonomists must act now. Taxon, 54, 1047-1050.

Cheffings, C.M., Farrell, L., Dines, T.D., Jones, R.A., Leach, S.J., McKeAn, D.R. et al. (2005) The vascular plant Red Data List for Great Britain. Species Status, 7, 1-116. Http://www.jncc.gov.uk/ pdf/pubo5_speciesstatusvpredlist3_web.pdf [accessed 5 July 2009].

Davidse, G., Sousa, S.M. \& Knapp, S. (eds) (1995) Flora Mesoamericana. Volumen 1. Psilotaceae a Salviniaceae. Instituto de Biología, UNAM, México.

FisHER, M. (2009) 2010 and all that-looking forward to biodiversity conservation in 2011 and beyond. Oryx, 43, 449-450.

Given, D.R. (1993) Changing aspects of endemism and endangerment in Pteridophyta. Journal of Biogeography, 20, 293-302.

GonzÁlez-Torres, L.R., Leiva Sachez, A.T., Rankin Rodríguez, R. \& Palmarola Bejerano, A. (eds) (2007) Categorización preliminar de taxones de la flora de Cuba-2007. Editorial Feijoo, Jardín Botánico Nacional, Universidad de la Habana, Habana, Cuba.

Hold Rid Ge, L.R. (1975) Zonas de vida ecológica de El Salvador. Food \& Agriculture Organization \& Dirección General de Recursos 
Naturales Renovables del Ministerio de Agricultura y Ganadería, Soyapango, El Salvador.

IUCN (2001) IUCN Red List Categories and Criteria (version 3.1). IUCN, Gland, Switzerland [http://www.iucnredlist.org/technicaldocuments/categories-and-criteria/2001-categories-criteria, accessed 5 July 2010].

IUCN (2009) IUCN Red List of Threatened Species v. 2009.1. Http:// www.iucnredlist.org [accessed 29 May 2009].

Jardín Botánico La Laguna (2010) Proyecto: Herramientas y Entrenamiento para La Conservación y Monitoreo de Helechos en El Salvador. Http://www.jardinbotanico.org.sv/proyectohelechos.htm [accessed 13 July 2010].

KLEKOWSKI, JR, E.L. (1982) Using components of the native flora to screen environments for mutagenic pollutants. In Environmental Mutagenesis, Carcinogenesis and Plant Biology (ed. E.L. Klekowski Jr), pp. 91-114. Praeger Scientific, New York, USA.

KnAPP, S. (2008) Species concepts and floras-what are species for? Biological Journal of the Linnean Society, 95, 17-25.

Knapp, S. \& Press, J.R. (2010) Floras to phylogenies-why descriptive taxonomy matters. In Beyond Cladistics: The Branching of a Paradigm (eds D.M. Williams \& S. Knapp) pp. 77-88. University of California Press, Berkeley, USA.

Krupnick, G., Kress, W.J. \& W a gner, W. (2008) Using Data from Museum Specimens to Build a Preliminary Conservation Assessment of Species. Paper presented at the Annual Meeting of the International Congress for Conservation Biology, Chattanooga, USA, 10 July 2008.

MARN (Ministerio del Ambiente y Recursos Naturales) (2000) Estrategía nacional de diversidad biológica. Ministerio del Ambiente y Recursos Naturales, San Salvador, El Salvador.

MARN (Ministerio del Ambiente y Recursos Naturales) (2004) Listado oficial de las especies de vida silvestre amenazadas o en peligro de extinción en El Salvador. Diario Oficial, Tomo 363(78), Acuerdo 10. Ministerio del Ambiente y Recursos Naturales, San Salvador, El Salvador.

MARN (Ministerio del Ambiente y Recursos Naturales) (2006) II Informe Nacional, Sistema de Areas Naturales Protegidas de El Salvador. Ministerio del Ambiente y Recursos Naturales, San Salvador, El Salvador.

MEA (Millennium Ecosystem Assessment) (2005) Ecosystems and Human Well-Being: Biodiversity Synthesis Report. Millennium Ecosystem Assessment, Island Press, New York, USA.

Monro, A.K., Jones, D.T. \& Araujo, M.E. (2006) Taxonomic capacity can improve environmental and economic sustainability in biodiversity-rich shade coffee farms in El Salvador. Systematics \& Biodiversity, 4, 1-8.

Monterrosa Salomón, J. \& Monro, A.K. (2008) An annotated checklist of the monilophytes (ferns) and lycophytes of El Salvador. Fern Gazette, 18, 120-215.

Monterrosa Salomón, J., Peña-Chocarro, M.C., Knapp, S. \& Escobar Lechuga, R. (2009) Guía de identificación de helechos de El Salvador. The Natural History Museum London \& Jardín Botánico La Laguna, San Salvador, El Salvador.

Moran, R.C. (2004) A Natural History of Ferns. Timber Press, Portland, USA, and Cambridge, UK.

Moran, R.C. (2008) Diversity, biogeography and floristics. In Biology and Evolution of Ferns and Lycophytes (eds T.A. Ranker \& C.H. Hauffler), pp. 367-394. Cambridge University Press, Cambridge, UK.

Orme, C.D.L., Davies, R.G., Burgess, M., Eigenbrod, F., Pickup, N., Olson, V.A. et al. (2005) Global hotspots of species richness are not congruent with endemism or threat. Nature, 436, 1016-1019.
PAGE, C.N. (1985) Epilogue-pteridophyte biology: the biology of the amphibians of the plant world. Proceedings of the Royal Society of Edinburgh, Section B, Biological Sciences, 86, 439-442.

Pryer, K.M., Schneider, H., Smith, A.R., Cranfill, R., Wolf, P.G., HunT, J.S. \& SiPES, S.D. (2001) Horsetails and ferns are a monophyletic group and the closest living relatives to seed plants. Nature, 409, 618-622.

Pryer, K.M., Schuettpelz, E., Wolf, P.G., Schneider, H., Smith, A.R. \& Cranfill, R. (2004) Phylogeny and evolution of ferns (monilophytes) with a focus on the early leptosporangiate divergences. American Journal of Botany, 91, 1582-1598.

Rabinowitz, D. (1981) Seven forms of rarity. In The Biological Aspects of Rare Plant Conservation (ed. H. Synge), pp. 205-217. John Wiley \& Sons, New York, USA.

RAMAS (2007) RAMAS RapidList: Preliminary Red List Assessment Tool. Http://www.ramas.com/RapidList.htm [accessed 5 July 2010].

Rodrigues, A.S.L., Pilgrim, J.D., Lamoreux, J.F., Hoffmann, M. \& Broокs, T.M. (2006) The value of the IUCN Red List for conservation. Trends in Ecology \& Evolution, 21, 71-76.

Smith, A.R., Pryer, K.M., Schuttpelz, E., Korall, P., Schneider, H. \& Wolf, P. (2008) Fern classification. In Biology and Evolution of Ferns and Lycophytes (eds T.A. Ranker \& C.H. Hauffler), pp. 417-467. Cambridge University Press, Cambridge, UK.

Tuomisto, H. (2006) Edaphic niche differentiation among Polybotrya ferns in western Amazonia: implications for coexistence and speciation. Ecography, 29, 273-284.

Tuomisto, H. \& Poulsen, A.D. (1996) Influence of edaphic specialization of pteridophyte distribution in Neotropical rainforests. Journal of Biogeography, 23, 283-293.

UNEP (United Nations Environment Programme) (2002) Global Strategy for Plant Conservation. COP decision VI/9. United Nations Environment Programme, CBD Secretariat, Montreal, Canada.

Ventura, N.E. \& Villacorta, R.F. (2001) Mapeo de vegetación natural de ecosistemas terrestres y acuaticos de El Salvador (CD Rom). Ministerio de Medio Ambiente y Recursos Naturales, San Salvador, El Salvador.

Walpole, M., Almond, R.E.A., Besançon, C., Butchart, S.H.M., Campbell-Lendrum, D., Carr, G.M. et al. (2009) Tracking progress toward the 2010 target and beyond. Science, 325, 1503-1504.

Wilson, K.A., Cawardine, J. \& Possingham, H.P. (2009) Setting conservation priorities. Annals of the New York Academy of Sciences, 1162, 237-264.

Wolf, P.G., Schneider, H. \& Ranker, T.A. (2001) Geographic distributions of homosporous ferns: does dispersal obscure evidence of vicariance? Journal of Biogeography, 28, 263-270.

Young, K. \& León, B. (1989) Pteridophyte species diversity in the Central Peruvian Amazon: importance of edaphic specialization. Brittonia, 41, 388-395.

\section{Biographical sketches}

SANDRA KNAPP is one of the editors of Flora Mesoamericana, a synoptic account of the vascular plants of southern Mexico and the republics of Central America. She is a specialist in the taxonomy and evolution of the Neotropical flowering plant family Solanaceae, especially the megadiverse genus Solanum. Jorge Monterrosa SALOMÓN is the curator of the herbarium at LAGU and specializes in the taxonomy and distribution of ferns and fern allies in El Salvador and the isthmus of Central America. He is involved in using collection data to help implement conservation policy on a national scale. 